Fixed Point Theory, 20(2019), No. 1, 323-336

DOI: $10.24193 /$ fpt-ro.2019.1.21

http://www.math.ubbcluj.ro/ nodeacj/sfptcj.html

\title{
A NEW APPROACH ON COUPLED FIXED POINT THEORY IN JS-METRIC SPACES
}

\author{
TANUSRI SENAPATI* AND LAKSHMI KANTA DEY** \\ *Department of Mathematics, National Institute of Technology Durgapur \\ West Bengal, India \\ E-mail: senapati.tanusri@gmail.com \\ ** Department of Mathematics, National Institute of Technology Durgapur \\ West Bengal, India \\ E-mail: lakshmikdey@yahoo.co.in
}

\begin{abstract}
In this article, we study coupled fixed point theorems in newly appeared JS-metric spaces. It is important to note that the class of JS-metric spaces includes standard metric spaces, dislocated metric spaces, $b^{\prime}$-metric spaces, modular spaces etc. The purpose of this paper is to present several coupled fixed point results in a more general way. Moreover, the techniques used in our proofs are indeed different from the comparable existing literature. Finally, we present non-trivial examples to validate our main results.
\end{abstract}

Key Words and Phrases: Metric space, partially ordered set, coupled fixed point.

2010 Mathematics Subject Classification: 47H10, 54E50.

Acknowledgements. Both the authors awe a debt gratitude to the anonymous referee for careful reading and helpful suggestions which considerably improve the first draft as well as the revised version. This work is funded by DST-INSPIRE, New Delhi, India under INSPIRE fellowship scheme (No. DST/INSPIRE FELLOWSHIP/2013/636). The support is gratefully acknowledged.

\section{REFERENCES}

[1] V. Berinde, Generalized coupled fixed point theorems for mixed monotone mappings in partially ordered metric spaces, Nonlinear Anal., 74(18)(2011), 7347-7355.

[2] T.G. Bhaskar, V. Lakshmikantham, Fixed point theorems in partially ordered metric spaces and applications, Nonlinear Anal., 65(2006), 1379-1393.

[3] M.F. Bota, A. Petruşel, G. Petruşel, B. Samet, Coupled fixed point theorems for single-valued operators in b-metric spaces, Fixed Point Theory Appl., 2015(2015), no. 231.

[4] H.S. Ding, L. Li, Coupled fixed point theorems in partially ordered cone metric spaces, Filomat, 25(2011), no. 2, 137-149

[5] D. Guo, V. Lakshmikantham, Coupled fixed points of nonlinear operators with applications, Nonlinear Anal., 11(5)(1987), 623-632.

[6] H. Isik, D. Turkoglu, Coupled fixed point theorems for new contractive mixed monotone mappings and applications to integral equations, Filomat, 28(6)(2014), 1253-1264. 
[7] H. Isik, S. Radenović, A new version of coupled fixed point results in ordered metric spaces with applications, U.P.B. Sci. Bull., Series A, 79(2017), no. 2, 131-138.

[8] M. Jleli, B. Samet, A generalized metric space and related fixed point theorems, Fixed Point Theory Appl., 2015(2015), no. 61.

[9] V. Lakshmikantham, L.B. Ćirić, Coupled fixed point theorems for nonlinear contractions in partially ordered metric spaces, Nonlinear Anal., 70(12)(2009), 4341-4349.

[10] A. Petruşel, G. Petruşel, B. Samet, J.C. Yao, Coupled fixed point theorems for symmetric contractions in b-metric spaces with applications to operator equation systems, Fixed Point Theory, 17(2)(2016), 459-476.

[11] S. Radenović, Remarks on some coupled coincidence point results in partially ordered metric spaces, Arab J. Math. Sci., 20(1)(2014), 29-39.

[12] S. Radenović, Coupled fixed point theorems for monotone mappings in partially ordered metric spaces, Kragujevac J. Math., 38(2)(2014), 249-257.

[13] T. Senapati, L.K. Dey, D. Dolićanin-Dekić, Extension of Ćirić and Wardowski type fixed point theorems in D-generalized metric spaces, Fixed Point Theory Appl., 2016(2016), no. 33.

Received: July 6, 2016; Accepted: June 19, 2017. 
